MILITARY TECHNICAL COLLEGE CAIRO - EGYPT

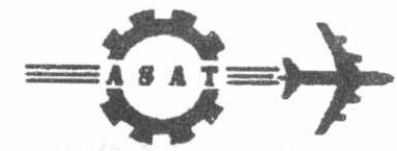

$7^{\text {th }}$ INTERNATIONAL CONF. ON AEROSPACE SCIENCES \& AVIATION TECHNOLOGY

\title{
ABRASIVE WEAR OF Al-Mg and Al-Mg2 Si-Si ALLOYS
}

\section{ABSTRACT:}

\author{
Dr. Mohamed M. Abbady
}

The abrasive wear (weight loss) of $\mathrm{Al}-4.4 \% \mathrm{Mg}$ and $\mathrm{Al}-4.30 \% \mathrm{Mg}-5.4 \% \mathrm{Si}$ (Al$\mathrm{Mg}_{2} \mathrm{Si}-\mathrm{Si}$ ) alloys is investigated. It is found that as applied stress and the grain size of the abrasive material increase, the weight loss increases as the sliding distance increases. As hardness increase; the weight loss decreases. Carrying out abrasive wear on one surface rather than different surfaces shows high weight loss. $\mathrm{Al}_{\mathrm{Mg}} \mathrm{Mi}-\mathrm{Si}$ $(\mathrm{Al}-4.3 \% \mathrm{Mg}-5.4 \% \mathrm{Si})$ alloy is heat-treatable and has hardness higher than $\mathrm{Al}-7 \% \mathrm{Si}$ and $\mathrm{Al}-11.5 \% \mathrm{Si}$ (eutectic) alloys. $\mathrm{Mg}_{2} \mathrm{Si}$ has density equals to $1.88 \mathrm{gm} / \mathrm{cm}^{3}$. Therefore $\mathrm{Al}-\mathrm{Mg}_{2} \mathrm{Si}$ alloys are recommended to be used in aircraft industry, missiles components and armor plates.

\section{KEYWORDS :}

Abrasive wear, $\mathrm{Al}-\mathrm{Mg}$ and $\mathrm{Al}-\mathrm{Mg}-\mathrm{Si}$ alloys.

\section{INTRODUCTION :}

Wear is the slow, undesired change of dimension in service resulting from pressure exerted by some other body and motion relative to it. Wear tends to decrease the dimension of machine parts. It changes the degree of fit, exposing moving part to unbalanced stresses, the existence of which may increase the possibility of failure by fatigue or other causes. Abrasive wear occurs because the hard particles dig into the metal and tear off the projecting burr that results. As hard metals ought to resist the penetration of the abrasive better, and the tough material would resist the tearing off
process [1].

Aluminum alloys have $4.5-5.5 \% \mathrm{Mg}$ are used in marine, auto and aircraft application, transportation equipment, missile components, armor plate and high strength welded structure [2]. An equation to express the abrasive wear rate has been derived for the case where a hard particle interact with a flat soft body [3].

$$
\mathrm{Q}=\mathrm{q} / \mathrm{S}=\beta \mathrm{W} / \mathrm{H}
$$

where : $Q=$ total wear volume per unit sliding distance, $q=$ wear rate (wear/time), $S=$ sliding speed, $\beta=$ the probability of producing wear fragment (abrasive wear constant), $W=$ normal applied load, $\mathrm{H}=$ the hardness of soft metal. 
Magnesium is the major constituent in the aluminum - magnesium group of alloys which achieve high strength with good ductility through cold work. These alloys have excellent corrosion resistance and weld ability. The phase in equilibrium with aluminum is $\mathrm{Mg}_{2} \mathrm{Al}_{3}$ ( $\mathrm{Mgs} \mathrm{Al}_{8}$ ). The yield stress, ultimate tensile strength, and Vickers hardness increase as $\mathrm{Mg} \%$ increase up to $15 \% \mathrm{Mg}$ for the as annealed and cold worked condition. Al-Mg alloys are wrought alloys but unheat - treatable. It can be heat - treatable by forming $\mathrm{Mg} 2 \mathrm{Si}, \mathrm{Mg}$ $\mathrm{Zn}_{2}, \ldots$ [4]. This is equals to $\mathrm{Al}-\mathrm{Si}$ alloys with $\mathrm{Mg}$ addition to form $\mathrm{Al}-\mathrm{Mg} z$. SiSi alloys.

Several researches have been carried out to investigate the abrasive wear of $\mathrm{Al}$ - $\mathrm{Si}$ alloys after addition $\mathrm{Mg}, \mathrm{Al}_{2} \mathrm{O}_{3}, \mathrm{SiC}$ and graphite [5-13] to the alloy matrix, non for Al-Mg alloys only.

In this work, the abrasive wear of $\mathrm{Al}-4.4 \% \mathrm{Mg}$ and $\mathrm{Al}-4.30 \% \mathrm{Mg}-5.4 \% \mathrm{Si}$ will be investigated.

\section{EXPERUMENTAL WORK :}

Aluminum $5 \% \mathrm{Mg}$ alloy delivered by Egyptian Aircraft plant is remelted and poured into metallic mould this is the first alloy. The second alloy is formed, as $\mathrm{Al}-\mathrm{Mg}$ alloy is remelted a certain amount of master $\mathrm{Al}-50 \% \mathrm{Si}$ alloy is added to the molten metal. Waiting 10 minutes after silicon alloy addition, the molten Al-Mg-Si alloy is poured from $850 \mathrm{C}^{\circ}$ into a metallic mould. The amount of silicon alloy added is more than that the required amount to form $\mathrm{Mg}_{2} \mathrm{Si}$ in the alloy matrix, i.e there is excess free Si. The chemical analysis of the two alloys is shown in table (1):

Table (1): The chemical analysis of Al-Mg and Al-Mg-Si alloys

\begin{tabular}{|c|c|c|c|c|c|c|c|}
\hline \multirow{2}{*}{$\begin{array}{c}\text { Alloy } \\
\text { Designation }\end{array}$} & \multicolumn{6}{|c|}{ Chemical Composition \% } \\
\cline { 2 - 8 } & $\mathrm{Mg}$ & $\mathrm{Si}$ & $\mathrm{Mn}$ & $\mathrm{Fe}$ & $\mathrm{Cr}$ & $\mathrm{Cu}$ & $\mathrm{Zn}$ \\
\hline $\mathrm{Al}-\mathrm{Mg}$ & 4.40 & 0.15 & 0.43 & 0.36 & 0.13 & 0.06 & 0.04 \\
$\mathrm{Al}-\mathrm{Mg}-\mathrm{Si}$ & 4.30 & 5.40 & 0.49 & 0.41 & 0.15 & 0.06 & 0.04 \\
\hline
\end{tabular}

The abrasive wear specimens are block $23 \times 23 \times 30 \mathrm{~mm}$. The worn surface is $23 \times 23 \mathrm{~mm}$. The abrasive testing machine is the standard aggregates abrasive machine, shown in Fig. (A.1). The drum diameter is $610 \mathrm{~mm}$ and rotates at 30 r.p.m. This the peripheral speed $=0.96 \mathrm{~m} / \mathrm{sec}$.

The abrasive wear is carried out at 200, 350 and 500 revolutions. The weight loss is measured using electrical sensitive balance with accuracy 0.001 gm. It is used two jows for fixing the abrasive specimen. The first metallic jow weighs 1600 gms. The second is limon wood jow weighs 230 gms. The abrasive material is quartz sand and having two grain sizes $300 \mu \mathrm{m}$ and 600 $\mu \mathrm{m}$. The abrasive worn surfaces are investigated using scanning electron microscope. 

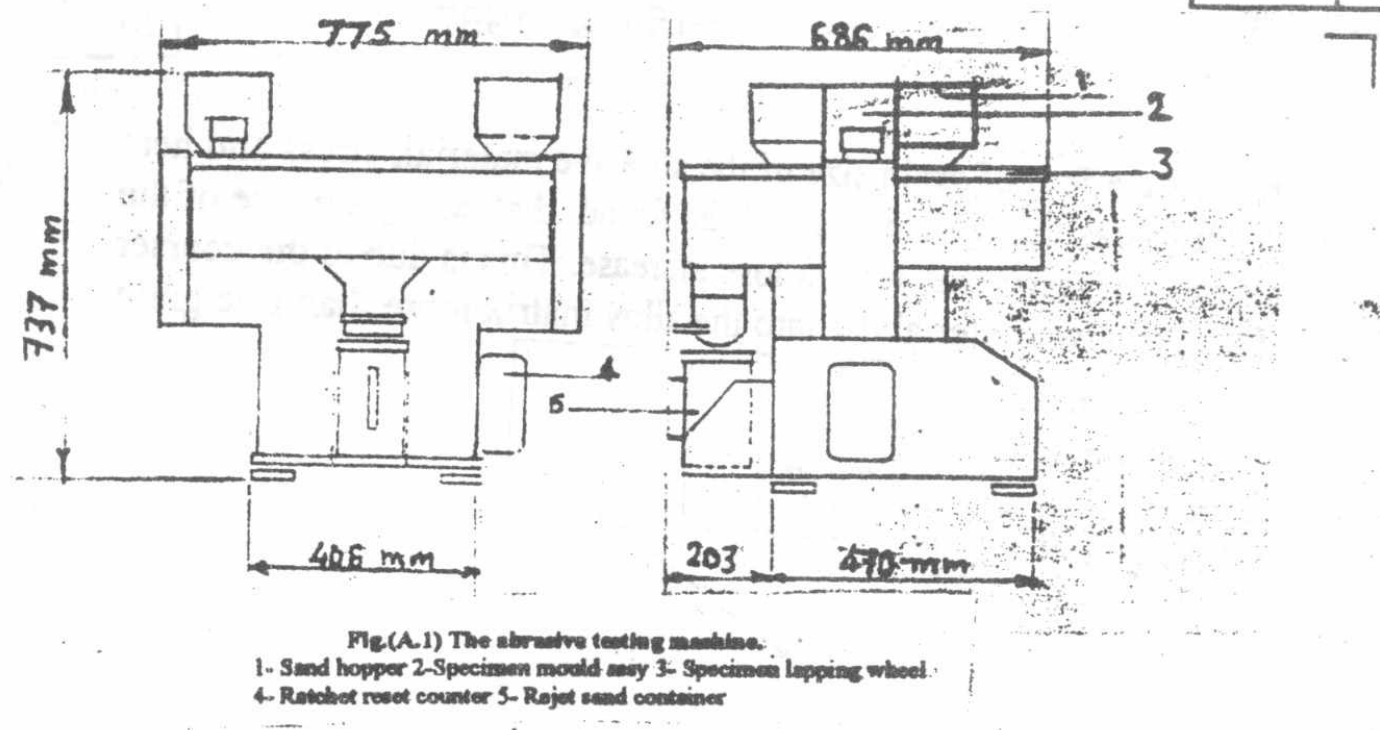

\section{RESULTS AND DISCUSSION:}

Fig 1 shows the effect of sliding distance on the abrasive weight loss for $\mathrm{Al}-4.4 \% \mathrm{Mg}$ and $\mathrm{Al}-4.30 \% \mathrm{Mg}-4.5 \% \mathrm{Si}$ in the as-cast condition. The abrasive material is quartz sand having grain size $=300 \mu \mathrm{m}$. It is noticed that as number of revolution (sliding distance) increases the weight loss increase: $\mathrm{Al}-\mathrm{Mg}-\mathrm{Si}$ alloy shows abrasive wear (weight loss) less than AI-Mgalloy This can be explained by the $\mathrm{Al}-\mathrm{Mg}-\mathrm{Si}$ alloy has two hard phases $\mathrm{Mg} 2 \mathrm{Si}$ and silicon. The required amount of $\mathrm{Si}$ to form $\mathrm{Mg} 2 \mathrm{Si}$ in $\mathrm{Al}-4.30 \% \mathrm{Mg}$ is $3.72 \%$. Si. Therefore $2.89 \%$ excess free silicon is in the matrix. This mean that as hardness increases, (the measured hardness is HRB $=61.25$ ), the abrasive wear (weight loss) detreases. This result coincides with results of many researches [14-18]: As the abrasive wear is carried out on the same surface rather than different surfaces (accumulative wear), the weight loss increases as sliding distance (number of revolution) increases. The accumulative weight loss is more than that weight loss for $\mathrm{Al}-\mathrm{Mg}$ alloy as the abrasive wear is carried out on different surfaces.

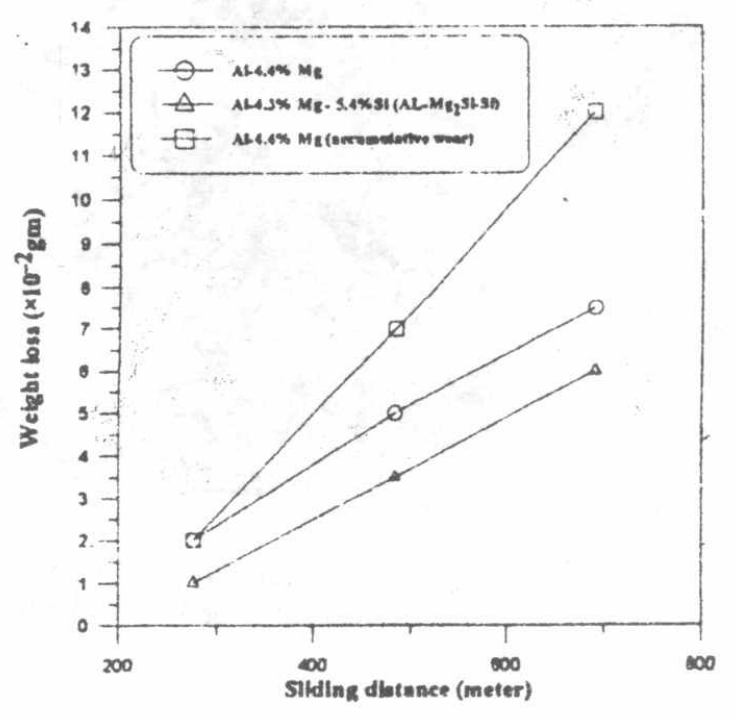

Fle 1 The ahrasive wear of Al-4.4\% Mg mad Al-4.3\%MES.4\%S! alloys, as cast (prain size of the abrastve matertal $=300 \mu \mathrm{m}$ ) 
Fig. 2 shows the effect of grain size of the abrasive material, stress and heat treatment on the abrasive weight loss. It is found that as grain size of the abrasive material increase, the weight loss increase. This is due to the coarser grain size of the abrasive material dig into the alloy matrix more than fine grain size.

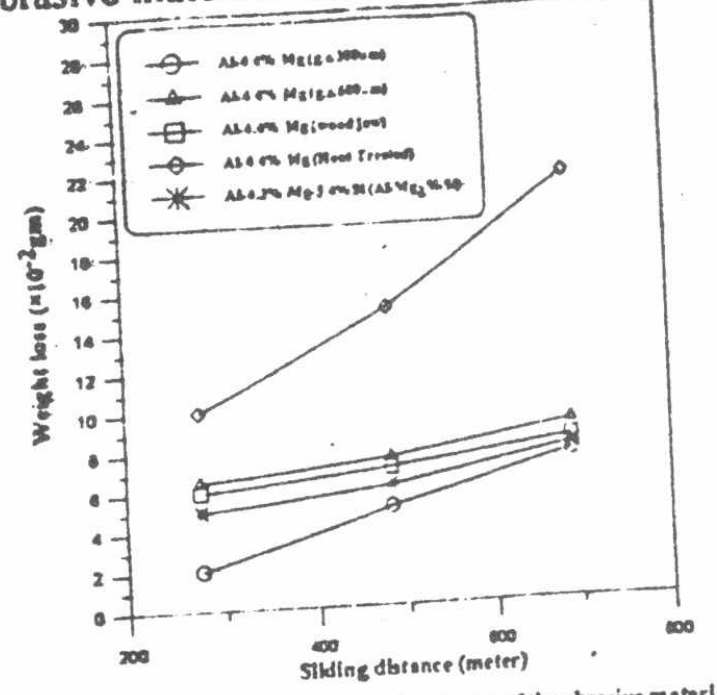

Tie 2 rect of atrese harjaesv and grain gise of the abrasive material (600w $m$ ) nn the weleht lose (HRB of At

Fig. 3 shows the micro structure of the as-cast $\mathrm{AI}-4.4 \% \mathrm{Mg}$ alloy. The dendritic structure is noticed clearly. Fig. 4 is for the same alloy after homogenizing at $540^{\circ} \mathrm{C}$ for 3 hours and water-quenched. There is a homogenized one phase. The measured hardness to this alloy is HRB $=50.6$.

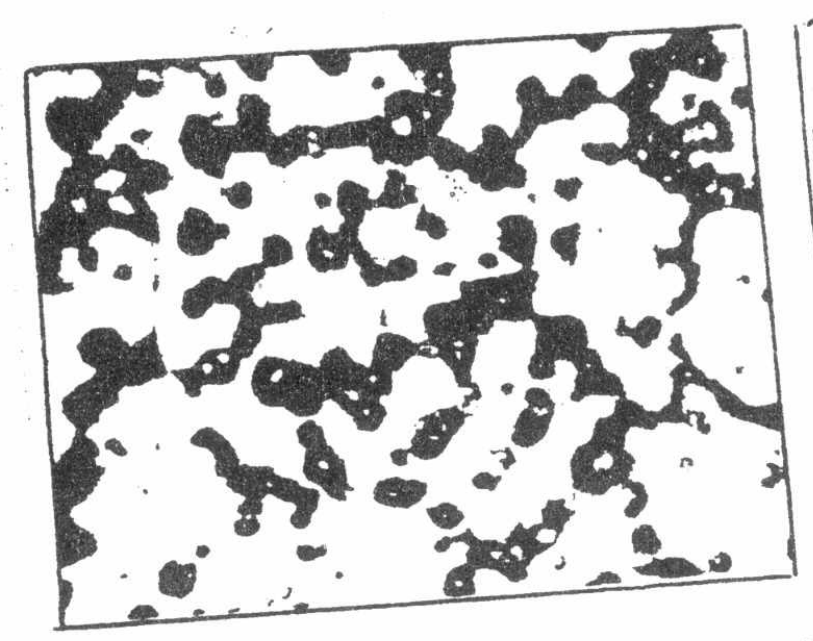

Fig. 3 The micro strutnure of $\mathrm{N}-4.4 \% \mathrm{M} g$ alloys (as-cost), $\times 100$.

Fig. 5 shows the effect of silicon addition on the micro structure of $\mathrm{Al}$ $4.4 \% \mathrm{Mg}$ alloy. The dendritic structure of Al-4.t\% Mg alloy is not seen. There is a modified structure of $\alpha$ ductile aluminum phase + eutectic structure $\left(\alpha^{+}\right.$, $\mathrm{Mg}_{2} \mathrm{Si}$ ). 


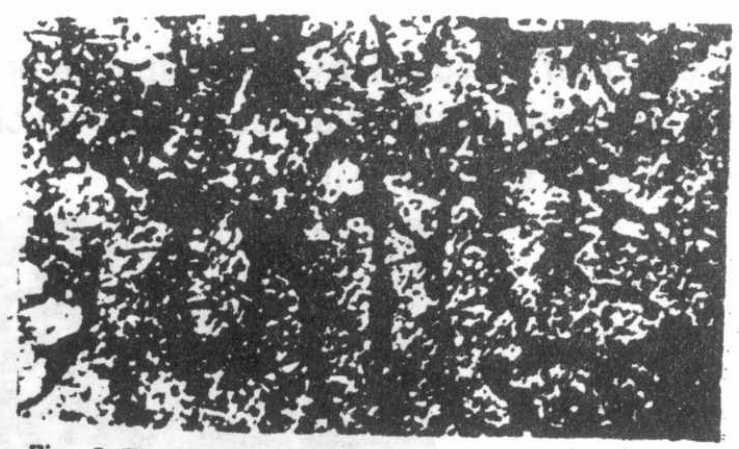

Fig. 5 The micro structure of AL-4:30\% Mg-5.t\%Si (as -
cast), $X 100$.

Fig. 6 shows the $\mathrm{X}$-rays diffraction of this alloy. It is found that there are $\mathrm{Al}, \mathrm{Mg}_{2} \mathrm{Si}$ and free silicon phase.

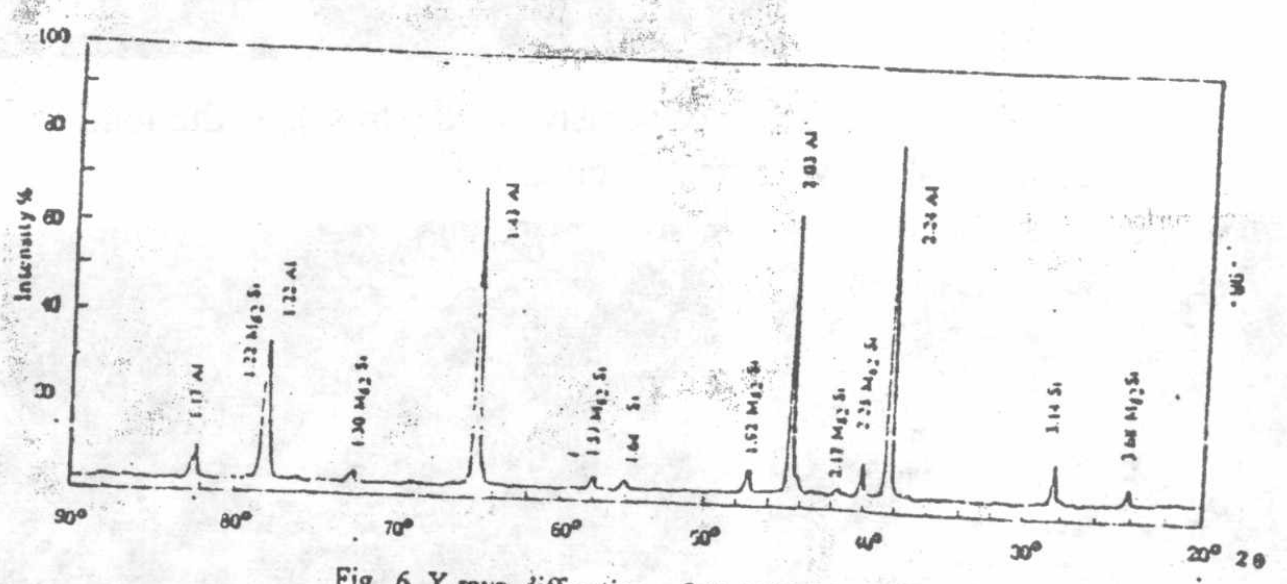

Fig. $6 \mathrm{X}$-rays diffraction of $\mathrm{Al}-4.30 \% \mathrm{Mg}-5.4 \% \mathrm{Si}$ shows

Figures $7-15$ show the scanning micrographes for selected abrasive worn surfaces. Fig. 7 and Fig. 8 show the effect of the grain size of the abrasive material for Al. $4.4 \% \mathrm{M}$. alloy. It is observed that as grain size increases the abrasive wear increase, wide grooves and more damage the worn surface.

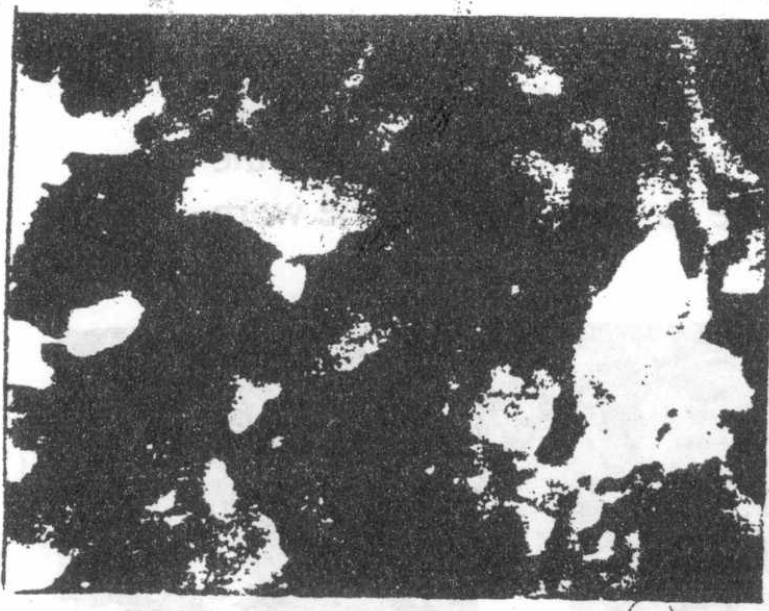

Fig. 7 The abrasive worn surface of $\mathrm{Al}-4.4 \% \mathrm{Mg}$ $(P=1.6 \mathrm{Kg}$. sliding distancic $=483 \mathrm{~m}$, abrasive $\mathrm{g} . \mathrm{s} .=600 \%$ m), $X_{n} 1000$ (SEM).

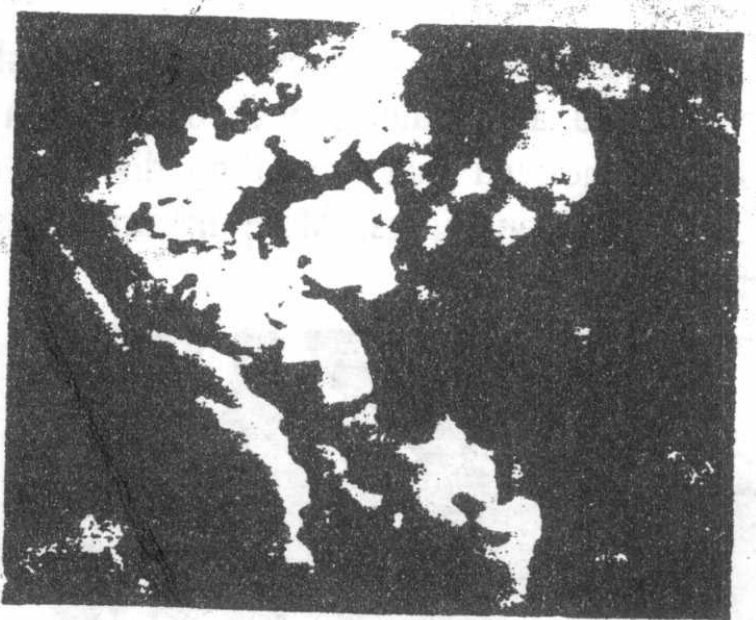

Fig. 8 The abrasive worn surface of $\mathrm{Al}-4.4 \% \mathrm{Mg}$ $(P=1.6 \mathrm{Kg}$. sliding distance $=483 \mathrm{~m}$, abrasive g...$=300 \mu$ m), X 1000 (SEM). 
Fig. 9 shows the effect of accumulative wear time on one surface rather than different surfaces. The grooves become more wide which indicate much material loss. The abrasive grain size is $300 \mu \mathrm{m}$.

Fig:9 The abrasive worn surface of $\mathrm{Al}-4.4 \% \mathrm{Mg}(\mathrm{P}=\mathrm{L} .6$ $\mathrm{K}_{8}$. sliding distance $\left.=276+483+690 \mathrm{~m}, \mathrm{~g} \cdot \mathrm{s}=300 \mu \mathrm{m}\right)$, X 1000 (SEM).

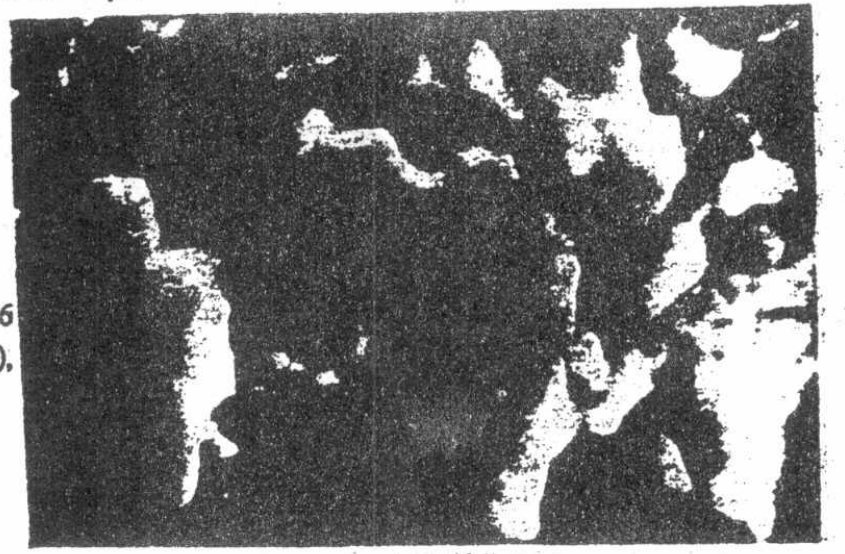

Fig. 10 and Fig. 11 show the effect of abrasive load (stress), as the load increases, more damage of the abrasive surface is observed.

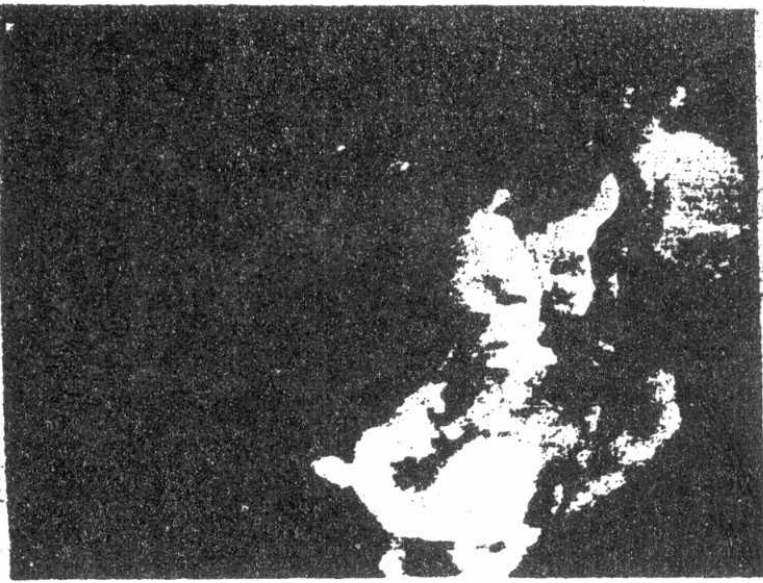

Fig. 10 The abrasive wom surface of $\mathrm{Al}-4.4 \% \mathrm{Mg}(\mathrm{P}=1.6$ $\mathrm{Kg}$, sliding distunce $=276 \mathrm{~m}, 8.3=600 \mu \mathrm{m}), \times 1000$ (SEM).

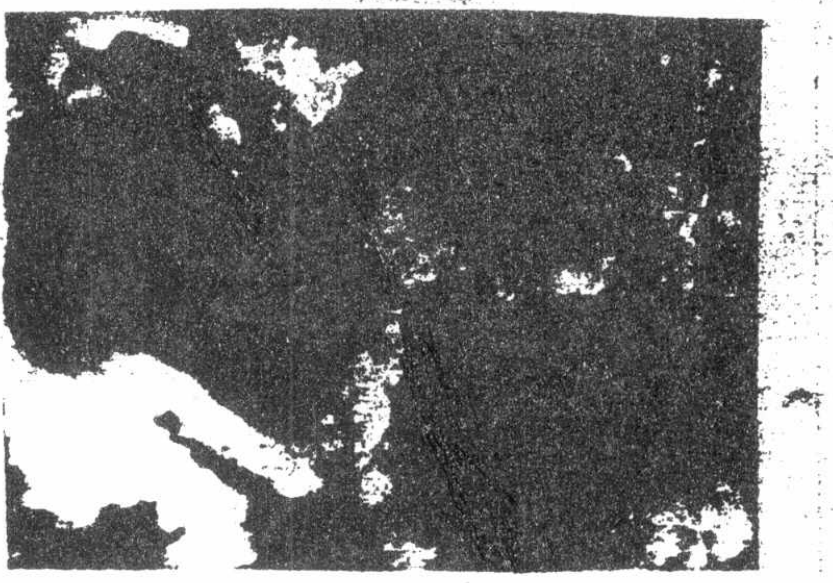

Fig. 11 The abrasive wom surface of $\mathrm{Al}-1.4 \%$. $\mathrm{Mg}$ $(P=0.23 \mathrm{Kg}$, sliding distance $=276 \mathrm{~m}, \mathrm{~g} \cdot \mathrm{s}=600 \mu \mathrm{m}), X$ 1000 (SEM).

Fig. 12 and Fig 13 show the effect of sliding distance for $\mathrm{Al}-4.4 \% \mathrm{Mg}$ as homogenized and water-quenched (solution treatment) on the abrasive weight loss. It is noticed that as sliding distance (no of revolution) increases, the abrasive wear increases. More material loss due to large area of the worn surface is removed.
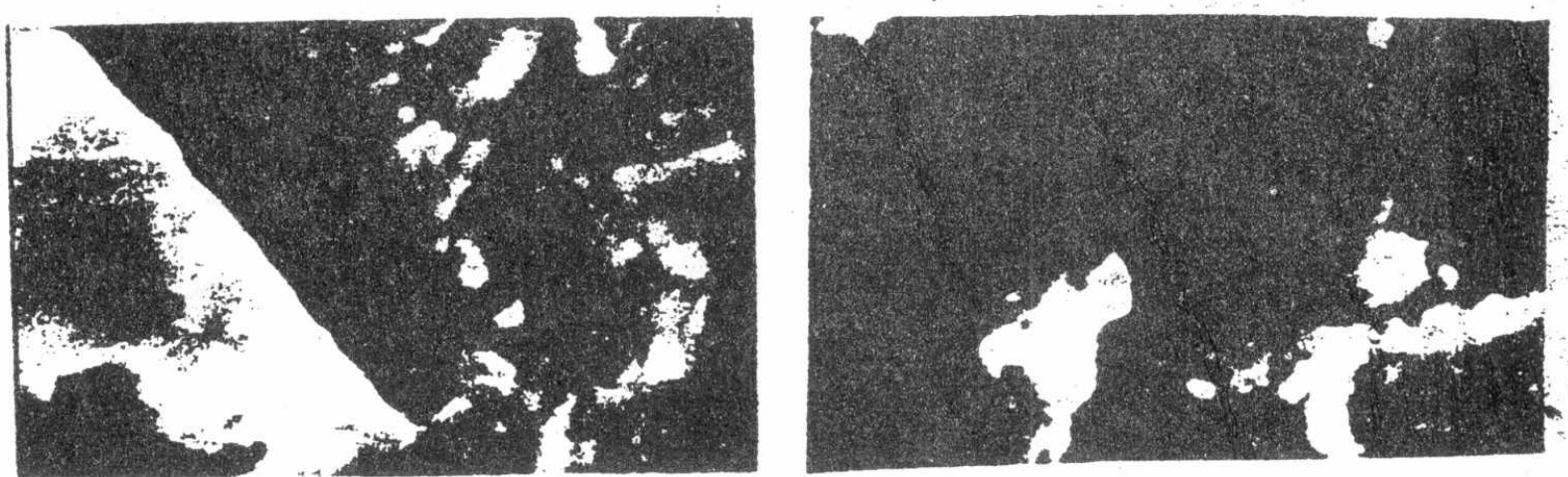

Fig 12 The sbrisive worm surface of $\mathrm{N}-4.49 . \mathrm{Mg}$ (Solution, (reatmest at $5+0^{\circ} \mathrm{C}$ for $3 \mathrm{hrs}$. and water quenchid), Pa $1.6 \mathrm{Ke}$ slidinge dierance $=690 \mathrm{~m} . \mathrm{gs}=600$, Lu1), $\times 1000$ (SE.U).

Fig 13 The abrasive worn surface of $1 /-4.4^{\circ}, \mathrm{Mg}$ (Sulution

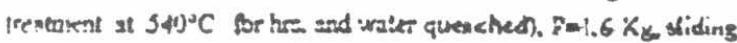
dislance $=483 \mathrm{~m}, \mathrm{gs}=600 \mathrm{\mu m}$, $\mathrm{X}$ (OOUU (SEM). 
Fig. 14 and Fig 15 show the effect of abrasive material grain size on the abrasive wear of $\mathrm{Al}-4.3 \% \mathrm{Mg}-5.4 \% \mathrm{Si}$ alloy. The weight loss increase as the abrasive material grain size increase. The micro graphs show free excess silicon (or silica grains embedded into) the alloy matrix.

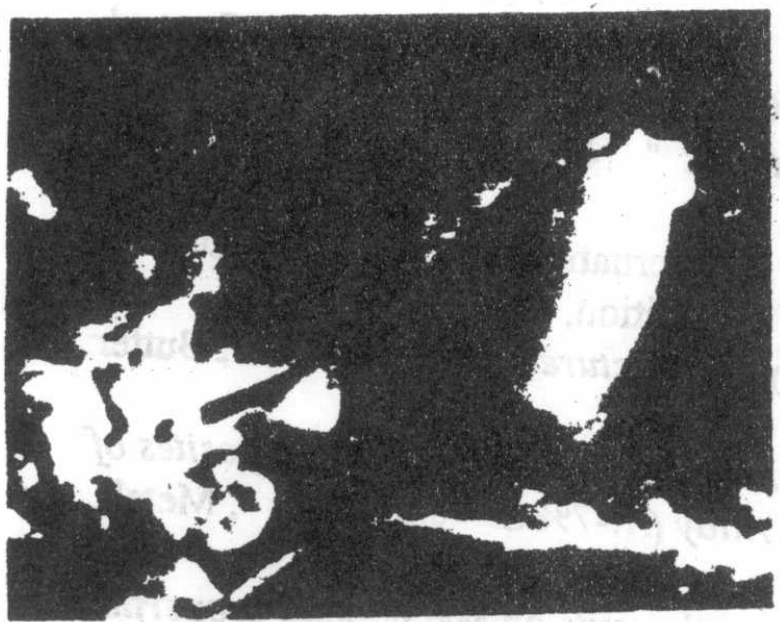

Fig. It The abrasive worn surface of $\mathrm{Al}-4.30 \% \mathrm{Mg}-5.4 \%$ $\mathrm{Si}$, as cast $(P=1.6 \mathrm{Kg}$, sliding distance $=690 \mathrm{~m} . \mathrm{g} . \mathrm{s}=600$ $\mu \mathrm{m}), \mathrm{X} 1000(\mathrm{EM})$.

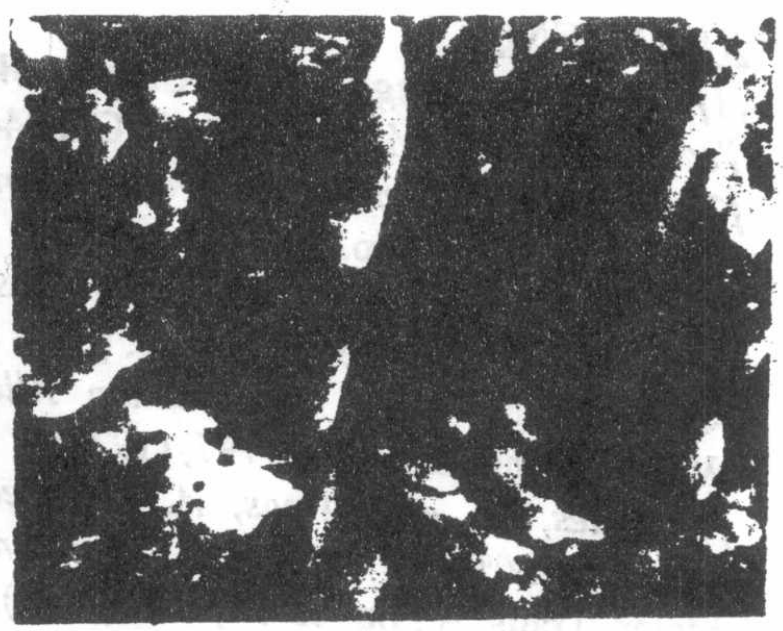

Fig. 15 The abrisile worn surface of $\mathrm{Al}-4.30 \% \mathrm{Mg}-5.4 \%$ $\mathrm{Si}$, as cast $(\mathrm{P}=1.6 \mathrm{Kg}$, sliding distance $=690 \mathrm{~m} . \mathrm{g} . \mathrm{s}=300$ $\mu \mathrm{m}), \times 1000$ (EM).

Finally $\mathrm{Mg}_{2} \mathrm{Si}$ and $\mathrm{Si}$ phases are very hard and corrosion resistance. Al$4.30 \% \mathrm{Mg}-5.4 \% \mathrm{Si}$ alloy is heat-treatable alloy. The Al-Si alloys are unheattreatable. Thus $\mathrm{Al}-4.30 \% \mathrm{Mg}-5.4 \% \mathrm{Si}(\mathrm{Al}-\mathrm{Mg} 2 \mathrm{Si}-\mathrm{Si})$ alloy is better than $\mathrm{Al}-\mathrm{Si}$ alloys. The hardness of Al-Mg2Si-Si alloy is $98 \mathrm{HV}$ for the as cast condition, while the hardness of $\mathrm{Al}-7 \% \mathrm{Si}$ alloy at the same condition equals to $47.4 \mathrm{HV}$ [19]. The hardness of the eutectic Al-Si alloy (11.5\% Si) equals to $60 \mathrm{HV}$ [20]. Therefore $\mathrm{Al}-4.3 \% \mathrm{Mg}-5.4 \% \mathrm{Si}$ can be used in aircraft industry, missiles, armor plates much better than Al-Mg alloys only.

\section{CONCLUSIONS:}

The abrasive wear of $\mathrm{Al}-\mathrm{Mg}_{2} \mathrm{Si}-\mathrm{Si}(\mathrm{Al}-4.5 \% \mathrm{Mg}-5.4 \% \mathrm{Si})$ alloy is better than $\mathrm{Al}-4.40 \% \mathrm{Mg}$ alloy. As the hardness increase the abrasive weariweight loss) decreases. Also as grain size of the abrasive material increases the weight loss of the worn alloy increases. It is found that as the applied load (stress) increases the weight loss increases. Carrying out the abrasive wear on one surface rather than different surfaces (for the same alloy at the same condition), the accumulative weight loss increases as sliding distance increases. $\mathrm{Al}-\mathrm{ilg} 2 \mathrm{Si}$ $\mathrm{Si}$ alloy shows better abrasive wear thamAl-4.4\% $\mathrm{VIg}$ alloy. Also $\mathrm{Al}-\mathrm{M} \mathrm{Mg}_{2} \mathrm{Si}-\mathrm{Si}$ alloy $((\mathrm{Al}-4.3 \% \mathrm{Mg}-5.4 \% \mathrm{Si})$ has hardness higher than $\mathrm{Al}-7 \% \mathrm{Si}$ and the eutectic Al-Si alloy (Al-11.5\% Si). $\mathrm{Mg}_{22} \mathrm{Si}$ has density equals to $1.88 \mathrm{gm} / \mathrm{cm}^{3}$. Thus $\mathrm{Al}-\mathrm{Mg}_{2} \mathrm{Si}-\mathrm{Si}$ alloy is tight alloy with high hardness and good abrasive wear. Therefore it can be used in aircraft industry, missiles components and annor plates. 
ACKNOWLEDGMENT:

The author would like to offer special thanks for authorities at Egyptian Aircraft Plant for supplying him with the Al- $5 \% \mathrm{Mg}$ alloy.

\section{REFERENCES:}

I1] David, A. Ringney and Glaeser W. A. "Surface Book on Wear Control . Technology", ASM, Metals Park, Ohio 44073 pp. 2-5, (1978).

[2] William, H., et. al., "Metals Handhook " Ninth Edition, ASM, Metals Park, Ohio 44073, pp. 102-104, (1978).

[3] Sarkaar, A. D., "Wear of Metals ", International Series in Materials. Science and Technology, Vol. 18, p. 94, First Edition, (1978).

[4] Mondolfo, L. F. " Aluminum Alloys : Structure and Properties: ", Butter Worths, London, pp. 313-797, (1979).

[5] Ames, W. and Alpas, A. T., "Wear Mechanism in Hybrid Composites of Graphite $20 \%$ Sic in A 356 Aluminum Alloy $(\mathrm{Al}-7 \% \mathrm{Si}-0.3 \% \mathrm{Mg}$ ) ", Metall. Mater. Trans. A., pp. 85-98, Jan. (1995).

[6] Yamada, K.; et al., "Effect of Alloying elements on:Mechanical properties of Carbon fiber Reinforced Aluminum Alloys ", Metals Abstract, ASM, Vol. 28, p. 236, (1994).

[7] Liaug, Y. N.; et ah, " Impact Abrasive Behavior of SiCp / 2024 Al. Composites in Single Pendulum Scralch Testing ", Wear, Vol. 178, 0-2, pp. 915, Nov. (1994).

[8] Axen, N.; and Jacobson, S., "A model for Abrasive. Wear Resistance of Multiphase Materials ", Wear, Vol. 174, pp. 187-199, (1994):

[9] Lin, S. J. and Liu, K. S., " Effect of Aging on Abrasive Rate in an Al-Zin Mg - Sic Composites ", Wear, Vol. 121, (1), pp. 1-14, Jan. (1988).

[10] Zhang, J. and Alpas A. T., "Wear Reginies in ceramic particulate Reinforced Aluminum Alloys". Friction, Lubrication and Wear Technology for Advanced Campsite Materials, Chicago, Illinois; Pittsburgh, Lensy/Vania, USA, (1992).

[11] Axen, N. and Jacobson S., "Transitions in the Abrasive Wear Resistance of Fiber-and Reinforced Aluminum", Wear, vol. 178(1-2), p. 1-7, Nov. (1994).

[12] Ravi, M.; et al., "A study of Influence of Misch metal Additions to Al$7 \%$, $1-0.3 \% \mathrm{Mg}$ All , Metall. and Mater. Trans. A, vol. 27A, P.1285-1292, May (1996).

[13] Yang, Liu; et al., "On the Role of Magnesitum and Silicon in the Formation of Alumina from Aluminum Alloys by Means of DIMOX Processing", Metall. and Mater Trains. A, Vol. 27A, P. 2094-2099, Aug. (1996).

[14] Yamanoto, T., et al., " Three-body Abrasive Wear of Ceramic Materials ", Wear, vol. 174, p $21-31$, (1994).

[15] Hung, N.P; Zhong, H., " Cumulative Tool Wear in Machining Metal Composites Part 1: Modeling", Joumal of Materials Processing Technology, Vol. 58, No. 1, P.109-113, Mar. (1996). 
[16] Garcia - Cordovilla, C.; et al., "Abrasive Wear Resistance of Aluminum Alloy/Ceramic Particulate Composites", Wear, Vol. 192 n1-2, P.170-177, Mar.(1996).

[17] Allen,CC., Ball, Ai, "Review of the Performance of Engineering Materials under Prevalent Tribological and Wear Situations in South African Industries.", Tribology International, Vol. 29, n2, P.105-116, Feb.(1996).

[18] Fujii, K.; et. al, " Friction and Wear of Aluminum Alloys Containing Hard Phases ", Journal of Tribology Transaction of the ASME, Vol. 117,n2, p-321327, Apr. (1995).

[19] Pramila, Bai, B.N.; Bis was, S.K. " Effect of Magnesium Addition and" Heat Treatment on Mild wear of Hypo eutectic Aluminum - Silicon Alloys.", Acta Metall. Mater., Vol. 39, No.5, P. 833-840, (1991).

[20] Abdel Salam A, et al, " Effect of Modification on the Sliding wearResistance of Al-Si Eutectic Alloys" , Proceeding - Third Conference of Theoretical and Applied Mechanics, Cairo 14-17 Nov., (1988). 